\title{
$X V$. Notices respecting new books. The course of creation
}

John Anderson D.D.

To cite this article: John Anderson D.D. (1850) XV. Notices respecting new books. The course of creation, Philosophical Magazine Series 3, 37:248, 145-146, DOI: $10.1080 / 14786445008646569$

To link to this article: http://dx.doi.org/10.1080/14786445008646569

曲 Published online: 30 Apr 2009.

Submit your article to this journal $\pi$

Џll Article views: 2

Q View related articles $\sqsubset$ 
ley is very much varied; on good land in good cultivation the crop is good, but on dry soils it is light and thin. A very small breadth of barley is sown this season. Wheat is very varied, the crop being from very bad to good according to the soils and management, the dry season having seriously affected the dry soils.

An unusually great breadth of spring wheat has been sown, displacing, as above stated, a portion of the barley crop.

Stock has generally done well where healthy, but Pneumonia has been very prevalent and fatal in some districts, generally among Irish cattle. Potatoes, from the dry cold weather, are later than usual.

\section{Notices respecting Nerw Books.}

The Course of Creation. By John Andrrson, D.D. London : Longman and $\mathrm{Co}$.

WE have been much gratified by the perusal of this work, not because at the present day physical science, and more especially the most poetical of all the branches of it, Geology, requires any defence from the reproach of being hostile to religion, but because the plain and simple yet forcible and eloquent manner in which the records graven upon the stone book of nature are set forth, have invested this production with unusual interest; and the more so, as emanating from the pen of a divine fully imbued with the important bearings which exist between natural science and revealed truth. "The Course of Creation" is no philosophic theory-involves no metaphysical inquiry into the origin of things-nor affords any new facts connected with the science itself; but is simply intended to express the feelings engendered in the mind of the author by geological pursuits; and thus it aims to impress others with a desire to become acquainted with the works of the Creator and the records of His will.

The subject-matter of the volume consists of the various geological phænumena to be met with in the line of country occurring between the Grampians and the Alps; and the relations of the several geological formations to each other are treated of in geographical sequence.

Thus we have the general structure of Scotland first mentioned, with its series of crystalline, trap and palæozoic rocks, including descriptions of the more important animal and vegetable remains found in the latter; to this succeeds the geological structure of England with its peculiar and interesting features, from the Silurian to the close of the tertiary period; the concluding geological portion is devoted to France and Switzerland, in which we find a concise account of the tertiary basin of Paris and the Loire, the volcanic district of Auvergne, and the structure of the Alps, \&c.

The descriptions are embodied not only from personal observation, but enriched by an extensive acquaintance with, and careful examination of, the most recent geological works.

We only notice one misstatement of any importance which appears Phil. Mag. S. 3. Vol. 37. No. 248. August 1850. 
to have escaped the author's attention: in speaking of the Swiss Alps, at p. 295 it is stated, that " the Oxfordian group are represented by the 'Neocomian' limestones, a series of strata abounding in fossils of the gault and upper greensand." According to Sir R. Murchison, Von Buch, and other geologists, the occurrence of the Oxfordian group with its characteristic shells is distinctly traced in the French and Swiss Alps, and forms the base of all the outer edges of the Savoy Alps, overlaid by the Neocomian limestones, which are again surmounted in the Savoy Alps by a dark-coloured limestone, which, from its contained fossils, fairly represents the gault and upper greensand.

The concluding part of the work is devoted to general principles, in which we find the theories of organic life discussed, especially as bearing on the development hypothesis,-the causes of extinction of the various forms of animated life which have successively tenanted our globe,- - the analogical order of moral and physical progression, -as well as a chapter on the Mosaic account of creation as reconcilable with geological discoveries; want of space prevents us from extracting the many valuable and eloquent passages contained in this portion, involving points of the highest interest.

To those who have not hitherto investigated the varied and multiform changes, both organic and inorganic, to which the superficial crust of our globe has been subjected, or have regarded geology as an unprotitable and uninviting study, and to the geologist himself occupied merely with the laborious task of collecting the dry statical details connected with his science, we cordially recommend the perusal of this volume, as unfolding in the plainest manner the beauty, harmony and beneficence of Creative power that has reigned throughout all past time, and by which the present surface of our earth has been elaborated, modified, and adapted to the wants of an intellectual and moral being, pointing out to us at the same time, that as an inquiry " into the records of Creation, geology has disclosed views, and elicited discoveries, of the works of the Divine Architect of the world which the religious inquirer will as cordially embrace, as ignorance can overlook or misapprehend."

\section{Proceedings of Learned Societies.}

CAMrRIdGe PHILOSOPHICAL SOCIETY.

[Continued from p. 69.]

Feb. 25, N the Symbols of Logic, the theory of the Syllogism, 1850. W and in particular of the Copula, and the application of the 'Theory of Probabilities to some questions of evidence. By Professor De Morgan.

This paper, which is in continuation of the one published in vol. viii. part 3 (read Nov. 9, 1846), and of subsequent additions contained in the author's work on Formal Logic, is divided into six sections.

Section I. On the approximation of logical and algebraical modes of thought.--The subjects of this section are,-1st, some development of the idea that the oppositions of logic have affinities which may 